\title{
Receptor Sites for the Primary Care Function: Reaction to the Paper by Karen Davis, PhD, and Kristof Stremikis, MPP
}

\author{
Kurt C. Stange, MD, PhD
}

In their article, "Family Practice: Preparing for a High Performance Health Care System," Karen Davis and her colleague and co-author Kristof Stremikis ${ }^{1}$ exhort readers to strengthen primary care as a key strategy for health care reform.

The authors say that there is wide consensus that primary care is at the center of a high-performing health care system. They give multiple hopeful examples of this high performance from primary care's reincarnation as the patient-centered medical home.

For participants in this 40th anniversary celebration of the founding of the American Board of Family Medicine (ABFM), this emphasis on the centrality of reformed primary care to meet the health care needs of Americans is a call to the "supper table of mom and apple pie." The call resonates with family physicians' hunger for acknowledgment and with the fullness of knowledge that systems based on primary care have higher quality, healthier people, less inequality in health care and health, and lower costs. ${ }^{2}$

But for many Americans, both rich and poor, this call to primary care is like a dog whistle. Sometimes we may see evidence of it in the resulting ruckus in the hounds around us, but we can't hear the call ourselves because our ears are not attuned to it-we don't have the receptor site.

Davis and Stremikis also present familiar and well-publicized Commonwealth Fund international comparative health care data that show how poorly the United States performs on patient-centered care. These data, validated by their consis-

From the Departments of Family Medicine, Epidemiology and Biostatistics, Sociology, and Oncology, Case Western Reserve University, Cleveland, Ohio.

Funding: Supported in part by a Clinical Research Professorship from the American Cancer Society.

Conflict of interest: none declared.

Corresponding author: Kurt C. Stange, MD, PhD, Case Western Reserve University, 10900 Euclid Ave, Cleveland, OH 44106 (E-mail: kcs@case.edu). tency and several years of replication, have a similar receptor-site problem. Americans, in general, are not receptive to learning from other countries.

Talking about the value of integrated, prioritized, personalized care at the ABFM is "preaching to the choir." But America is not one "choir. " Our disharmony is fueled by those whose self-interest is the status quo; whose mode of operation is to distort, distract, and divert our attention from the facts that point persistently to our commonality and to our personal and public need for a health care system based on primary care; and whose sound bites are designed to elicit a visceral reaction when we should be reacting and acting much further up on our anatomy-in that mystical spot where our hearts and our heads unite, where what is right and what is possible and what we do merge into a course that is about advancing our shared common good.

All of this information to inform and inspire action-the value of primary care; the knowledge that can be gleaned from natural experiments of intercountry, intersystem, and interpractice differences; and the inspiring examples of evolved family practices like the one discussed below-is lost because of the "lack of a receptor site."

Those of us in family medicine and primary care need to develop our receptor sites. We need to ramp up those points to which we can attach our venerable and still vital values to new ways of working. ${ }^{3}$ We need to recognize that many of the old values still apply, but many of our old ways of working do not.

The imperative for change comes from many fronts: the growing volume of what health care and primary care can do to treat illness and foster health, the aging population and explosion of chronic and behaviorally mediated illness, the need to leave some resources available to work on the social and environmental determinants of health rather than consuming more than our fair share of resources in the health care sector, and genera- 
Table 1. The Generalist Approach

Ways of being-Readiness for the generalist way

- Open stance (receptive to diverse perspectives and co-created knowledge)

- Humility

- Connection via key relationships

Ways of knowing-Training for the generalist way

- Broad knowledge (of self, others, systems, the natural world and their interconnectedness)

- Grounding (in specific knowledge and experience)

Ways of perceiving-Seeing the world in ways that foster integration

- Scanning and prioritizing, then focusing on the highest priority

- Focusing on the particulars while keeping the whole in view

Ways of thinking and doing-Prioritized, joined-up action

- Engaging with the most important parts in context

- Doing multiple low-level tasks to enable higher-level

integrative action over time

- Connecting

- Iterating (between breadth/depth, subjective/objective, parts/whole, action/reflection)

- Loving (putting another and a larger good before self)

Adapted from Stange KC. The generalist approach. Ann Fam Med 2009;7:198-203. ${ }^{5}$

tional and cultural differences in how we work and play and what we value. These and many other factors require us to embrace change.

As we learned recently from the findings of early evaluation of one of the demonstration projects mentioned above, family physicians making these changes need to undergo a personal transformation. ${ }^{4}$ This transformation involves learning to work as a team, reorganizing our practices so that our individual approach to putting the patient first is paralleled by systems that proactively integrate preventive care as well as chronic illness and mental health care in addition to reacting to the patient's immediate concern.

Even as we work to transform ourselves we need to work with others to create space for respectful dialogue about changes in which everyone will need to give some in the short term to get to a better place for all in the longer term. We can do this through generalist ideas and by fostering the "receptor sites" that all people have for the generalist approach.

As generalists, we begin with our recognition of participation in community and cosmos. We engage in certain ways of being, knowing, perceiving, thinking, and doing. ${ }^{5}$ These are outlined in Table 1. The generalist way involves being humble, connected, and open. It involves seeking broad knowledge grounded in specific experience and perceiving in ways that foster integration by scanning, prioritizing, and focusing on the most important particulars while keeping the whole in view. When we think and act in this generalist way we bring meaning to apparently low-level tasks that develop relationships and iterate between the parts and the whole to foster a larger good.

The apparently lower-level tasks that primary care performs are useful not just because of their own value, but because of their ability to enable higher-order health care. As shown in Figure 1, family physicians provide fundamental care. However, we provide higher levels of care that transcend

Figure 1. A hierarchy of health care. (From Stange KC. A science of connectedness. Ann Fam Med 2009;7: $387-95 .^{6}$ )

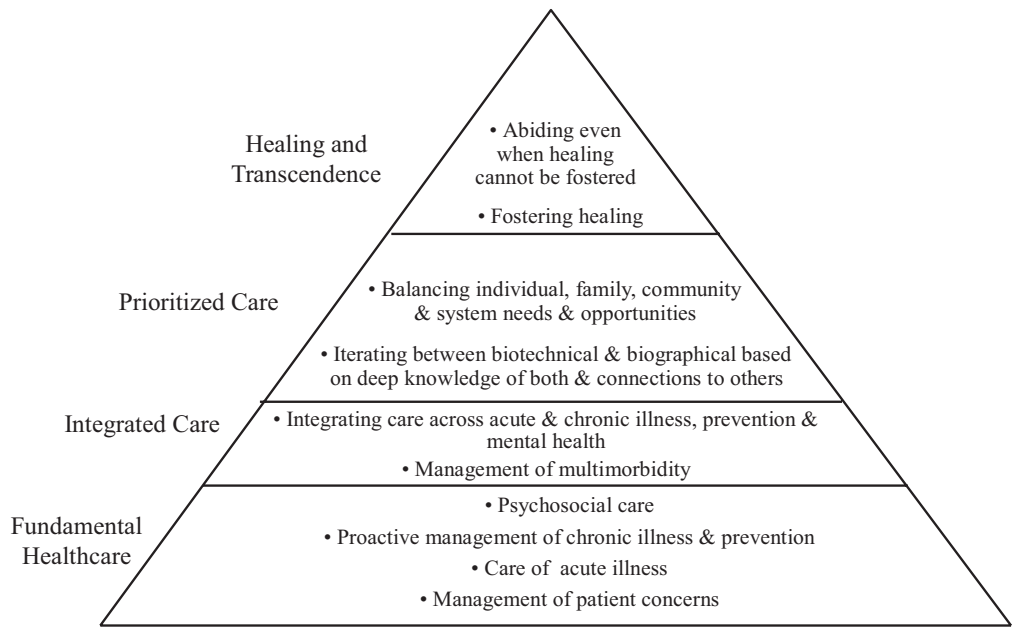


and include this fundamental care. ${ }^{6} \mathrm{We}$ integrate care across multiple illnesses and across the domains of acute and chronic illness, mental health, and prevention. We prioritize care across these domains and across the levels of the patient, family, community, and society. We provide a cure when possible, but we abide with patients over time and help them to transcend suffering when a cure is not possible. $^{7-9}$

Family practice is more than the fundamental levels that are all we know how to describe and measure and that are all that our systems support and value. Family physicians are fundamental to a high-functioning health care system. But we are more than fundamentalists. We integrate, personalize, and prioritize. When we are truly centered on patients and relationships, we stick with people through the important moments in life. As we transform ourselves and our practices and work with others toward larger system transformations, we need to be aware of the possible unintended consequences of working on the individual components without being aware of how the relationship of the parts enables a larger whole. ${ }^{10-12}$

Therefore, we'd like to close by adding one item our list of the 7 attributes of patient-centered care $^{13}$ : relationship. Patient-centered care is not a commodity that can be bought and sold in the commercial way we currently approach health care in the United States. It is a connection that cannot be assumed, but that needs to be named and invested in by both patients and practices and supported by a system. This mutual investment is necessary if something is to be known and valued. Research shows that patients come to value a relationship basis for health care through being with their family physician over time. They come to value the relationship if they feel that "this doctor and I have been through a lot together." If both longitudinality and this shared experience of being together through important life events are present, patients will do just about anything to continue this relationship. ${ }^{14,15} \mathrm{We}$ need to figure out what this means in the current context, and we need to figure out how to value and support it if we are to have a high-functioning health care system.

On its 40th anniversary the ABFM is showing leadership: the ABFM has sponsored the Future of Family Medicine Project and has used the findings from that project to develop new ways of training family physicians for its new model of care; has sponsored 2 journals that are trying to create space for ramping up the "receptor sites" for respectful dialogue about change toward a larger individual and collective good; has helped family physicians evolve to meet growing opportunities and responsibilities; and has moved the focus from the physician to the patient and has changed the practice and the system to enable healing.

I thank Dr. Davis and Mr. Stremikis for their insightful article. I congratulate the ABFM on its 40th anniversary and wish the current Board staff and diplomates the best in their work to enhance the ability of family physicians and primary care practices to meet the needs of the American people for high-level, high-value care that enables health.

I am grateful to Heide Aungst for helpful comments on an earlier draft of this article.

\section{References}

1. Davis K, Stremikis K. Family practice: preparing for a high-performance health care system. J Am Board Fam Med 2010;23(Suppl):S11-6.

2. Starfield B, Shi LY, Macinko J. Contribution of primary care to health systems and health. Milbank Q 2005;83:457-502.

3. Martin JC, Avant RF, Bowman MA, et al. The Future of Family Medicine: a collaborative project of the family medicine community. Ann Fam Med 2004;2(Suppl 1):S3-32.

4. Nutting PA, Miller WL, Crabtree BF, Jaén CR, Stewart EE, Stange KC. Initial lessons from the first national demonstration project on practice transformation to a patient-centered medical home. Ann Fam Med 2009;7:254-60.

5. Stange KC. The generalist approach. Ann Fam Med 2009;7:198-203.

6. Stange KC. A science of connectedness. Ann Fam Med 2009;7:387-95.

7. Scott JG, Cohen D, DiCicco-Bloom B, Miller WL, Stange KC, Crabtree BF. Understanding healing relationships in primary care. Ann Fam Med 2008; 6:315-22.

8. Egnew TR. The meaning of healing: transcending suffering. Ann Fam Med 2005;3:255-62.

9. Egnew TR. Suffering, meaning, and healing: challenges of contemporary medicine. Ann Fam Med 2009;7:170-5.

10. Stange KC, Jaén CR, Flocke SA, Miller WL, Crabtree BF, Zyzanski SJ. The value of a family physician. J Fam Pract 1998;46:363-8. 
11. Stange KC. The paradox of the parts and the whole in understanding and improving general practice. Int J Qual Health Care 2002;14:267-8.

12. Stange KC, Ferrer RL. The paradox of primary care. Ann Fam Med 2009;7:293-9.

13. Davis K, Schoenbaum SC, Audet AM. A 2020 vision of patient-centered primary care. J Gen Intern Med 2005;20:953-7.
14. Mainous AG 3rd, Goodwin MA, Stange KC. Patient-physician shared experiences and value patients place on continuity of care. Ann Fam Med 2004;2: 452-4.

15. Nutting PA, Goodwin MA, Flocke SA, Zyzanski SJ, Stange KC. Continuity of primary care: to whom does it matter and when? Ann Fam Med 2003;1: $149-55$. 